\title{
Utilization Practices and the Returns from Seeding an Area to Crested Wheatgrass
}

\author{
E. BRUCE GODFREY
}

\section{Abstract}

Numerous studies have estimated the benefits and costs of various types of range improvements, including seedings. However, the results reported have varied widely. One of the reasons why these estimates have varied is that the effect of utilization (season and amount) has generally not been explicitly considered. In an effort to provide some insight into the effect utilization has on returns, a study of the Point Springs seedings in south-central Idaho was undertaken. This study indicated that: (1) spring utilization of crested wheatgrass seedings is a necessary prerequisite to favorable net returns; (2) grazing patterns involving heavy utilization had the shortest life, but the highest net returns; (3) fall only utilization had the lowest net returns; (4) the net returns from seeding the area were greater than the investment costs for nearly all utilization patterns considered; and (5) seeding an area to crested wheatgrass can yield returns which may be greater than the returns from investing scarce investment dollars in other range improvement alternatives.

Various types of range improvements have been studied and evaluated by members of the Society for Range Management for many years. Numerous studies have evaluated the impact of season and intensity of use on factors such as reinvasion of sagebrush, animal gains, forage production, infiltration, and soil compaction. A large number of studies have also estimated the benefits and costs of various range improvement practices. Very little empirical work has been conducted, however, which evaluates the impact of season or intensity of use on the economic returns that might be expected from. any particular type of range improvement. This report is a summary ${ }^{1}$ of one study conducted in southern Idaho which evaluated the impact of alternative utilization patterns on the returns from seeding an area to crested wheatgrass.

\section{Study Area}

The Point Springs experimental grazing area was established through a cooperative agreement among the Bureau of Land Management (BLM), a group of local ranchers, and the University of Idaho. The study area, located in the Raft River Valley of Cassia County, Idaho, near the Utah-Idaho border, is typical of much of the dryer sagebrush-grass communities found throughout the Great Basin and the Snake River plains. Heavy grazing of the area by domstic livestock near the turn of the century resulted in decreased forage production. As a result, this area was seeded to crested wheatgrass (Agropyron

The author is associate professor, Utah State University, formerly on the staff at the University of Idaho. This study was sponsored by the Ag and Forest, Wildlife and Range Experiment Stations at the University of Idaho and relies primarily on the earlier work reported by Sharp (1970). This report is Idaho Agricultural Experiment Paper No. 7811.

Appreciation is expressed to Lee Sharp, Edgar Michaelson, Darwin Nielsen, and two antonymous reviewers for comments received which improved the readability of this report.

Manuscript received January 13, 1978.

'Readers desiring additional detail should consult the publications by Sharp (1970) or Godtrey and Sellasie (1978). cristatum and $A$. desertorum) during the fall of 1952. Grazing was deferred until 1955, when experimental grazing trials began which were designed to evaluate the impact of different seasons and intensities of use on various parameters.

The original experimental trials consisted of grazing six 160-acre pastures during the spring or fall. In 1960 the original design was altered by dividing the 160 -acre pastures in two and grazing six pastures during the spring or fall and six during the spring and fall (Fig. 1). Cattle were placed in each pasture in sufficient numbers to achieve three expected levels of total utilization-light (50\% utilization), moderate ( $65 \%$ utilization), or heavy ( $80 \%$ utilization)which were generally different from the actual level of utilization which occurred. These trials continued through the 1970 grazing season, when the experiment was altered. Forage production and utilization were measured starting in 1955 and have been the basis for a number of studies conducted by personnel at the University of Idaho. Yearling cattle used during the experiment were supplied by local ranchers and were weighed on and off the pastures involved. Thus, a relatively complete data set was available that measured how alternative utilization patterns affected animal grazing, forage production, and other ecological parameters.

Records available from the Burley District (BLM) indicated that the direct seeding costs ( $\$ 6.51$ per acre) were generally of the same order of magnitude as the seeding costs of other projects that werc established in southern Idaho during this period (Caton and Beringer 1960 ). However, the Point Springs project also included considerable fencing and water developments (wells, pipelines, troughs, and pumps which made the total investment costs ( $\$ 15.57$ per acre) for this projert higher than that of similar seedings established in this area.

BLM personnel estimated the carrying capacity of the area to be 27 acres per AUM before the project was initiated. They also estimated that animals grazing this area were gaining 1.4 pounds per day. From this basic information, it was estimated (Godfrey and Sellassie 1978) that 1.6 pounds of gain per acre would have been foregone during the deferment period (1953 and 1954). It was also assumed that the 1.6 pounds of gain per acre would have been obtained if these seedings had not been established (after 1954).

\begin{tabular}{|c|c|c|c|c|c|}
\hline $\begin{array}{l}\text { Moderate } \\
\text { Spring } \\
\text { Heavy } \\
\text { Fall } \\
10\end{array}$ & $\begin{array}{l}\text { Light } \\
\text { Fall }\end{array}$ & $\begin{array}{l}\text { Light } \\
\text { Spring }\end{array}$ & $\begin{array}{l}\text { Light } \\
\text { Spring } \\
\\
\text { Light } \\
\text { Fall } \\
20\end{array}$ & $\begin{array}{l}\text { Heavy } \\
\text { Spring }\end{array}$ & $\begin{array}{l}\text { Light } \\
\text { Spring } \\
\text { Moderate } \\
\text { Fall } \\
\quad 30\end{array}$ \\
\hline $\begin{array}{c}\text { Moderate } \\
\text { Fall }\end{array}$ & $\begin{array}{l}\text { Light } \\
\text { Spring } \\
\\
\text { Moderate } \\
\text { Fall } \\
60\end{array}$ & $\begin{array}{l}\text { Moderate } \\
\text { Spring }\end{array}$ & $\begin{array}{l}\text { Moderate } \\
\text { Spring } \\
\\
\text { Light } \\
\text { Fall } \\
50\end{array}$ & $\begin{array}{c}\text { Heavy } \\
\text { Fall }\end{array}$ & $\begin{array}{l}\text { Light } \\
\text { Spring } \\
\\
\text { Heavy } \\
\text { Fall } \\
40\end{array}$ \\
\hline
\end{tabular}

Fig. 1. Point Springs experimental pasture design. 


\section{Results and Discussion}

The preceding data provided the basis for a economic evaluation of the seedings at Point Springs. While most readers recognize that range improvements that are established for various reasons, the following analysis assumes that the Point Springs project, like most similar improvements that were established during the 1950 's, was established with the primary purpose of increasing domestic animal production.

\section{Estimated Actual Returns}

The benefits obtained as a result of establishing the Point Springs seeding were determined in the following manner. The amount of animal gain (weight of animals taken off a pasture minus their "in" weight) was measured directly. This gain was then divided by the number of acres in the pasture where the animals grazed. The 1.6 pounds of gain per acre that was assumed would occur "without" the seeding was then subtracted from these gains. The difference represented the net gain "with" the project. These net gains were then multiplied by various prices and discounted to the beginning of 1953 for comparison with the costs incurred to seed the area involved. For example, the gains for the Point Springs pasture (Pasture 03, Fig. 1), which was used heavily during the spring, yielded gains which had a present value of $\$ 130.35$ per acre

$$
\left.1 \frac{30 \notin(0-1.6)}{(1.06)^{1}}+\frac{30 \notin(0-1.6)}{(1.06)^{2}}+\frac{30 \notin(33.4-1.6)}{(1.06)^{3}}+\ldots+\frac{30 \notin(56.3-1.6)}{(1.06)^{14}}\right]
$$

when a $6 \%$ discount rate and 30 cents per pound of gain is assumed. This present value was greater than the investment costs incurred ( $\$ 15.57$ per acre). Present values for the other Point Springs pastures are found in Table 1. These data indicate that when a $6 \%$ discount rate and 30 cents per pound of gain are assumed, every grazing pattern (season and intensity) yielded net returns (present value of gains with the seedings minus the present value of gains without the seeding) that were grater cate that when a $6 \%$ discount rate and 30 cents per pound greater than the investment cost (\$15.57) incurred." Large differences in net returns exist between the grazing patterns, however. For exanple, pastures which were grazed only during the fall had net returns that were less than half as large as pastures which were grazed to some degree during the spring. This pattern closely parallels the results reported earlier by Currie (1970) for Colorado. This also indicates that grazing crested wheatgrass during the spring is generally a necessary condition for high net returns in the form of livestock production.

The results in Table 1 not only indicate that grazing during the spring results in higher net returns than grazing in the fall, but that these net returns increase with the intensity of grazing-i.e., net returns from heavy spring grazing were greater than moderate spring, which were, in turn, greater than light spring grazing. Returns obtained from grazing pastures during the spring and fall, however, did not follow as consistent a pattern with respect to grazing intensity as was evident for pastures which were only grazed during spring or fall. Moderate spring grazing, when combined with fall grazing, generally resulted in net returns that were higher than most alternative grazing patterns. These results not only show that some of the returns obtained at Point Springs were as large or larger than

"The criterion of positive net benefits (present value of net returns minus investment costs) is only one of several criteria that could have been used. The other criteria that are often used include benefit-cost ratios and internal rates of return. Discussions of these criteria and their major strengths and weaknesses are found in numerous sources-e.g. . McKcan (1958), Mcrewitz and Sosnick (1971), LaBaron (1963). Prest and Turvey (1965)
Table 1. Total discounted (6\% discount rate) net revenue per acre, Point Springs Experimental Pastures, southern Idaho, 1955-1970.

\begin{tabular}{|c|c|c|c|c|}
\hline Rank & $\begin{array}{l}\text { Grazing system } \\
\text { (stocking rates } \\
\text { associated with } \\
\text { season) }\end{array}$ & $15 c$ & $\begin{array}{c}\text { Price pe } \\
30 \varnothing\end{array}$ & $45 \varnothing$ \\
\hline 1 & Heavy spring & 65.18 & 130.35 & 195.53 \\
\hline 2 & $\begin{array}{l}\text { Moderate spring, } \\
\text { moderate fall }\end{array}$ & 61.41 & 122.82 & 184.23 \\
\hline 3 & $\begin{array}{l}\text { Moderate spring, } \\
\text { light fall }\end{array}$ & 59.72 & 119.45 & 179.17 \\
\hline $\begin{array}{l}4 \\
5\end{array}$ & $\begin{array}{l}\text { Moderate spring } \\
\text { Light spring, }\end{array}$ & 57.92 & 115.85 & 173.77 \\
\hline & light fall & 52.10 & 104.19 & 156.29 \\
\hline 6 & Light spring & 50.09 & 100.18 & 150.27 \\
\hline 7 & $\begin{array}{l}\text { Moderate spring } \\
\text { heavy fall }\end{array}$ & 39.96 & 79.93 & 119.89 \\
\hline 8 & $\begin{array}{l}\text { Light spring, } \\
\text { heavy fall }\end{array}$ & 36.72 & 73.45 & 110.17 \\
\hline 9 & $\begin{array}{l}\text { Light spring, } \\
\text { moderate fall }\end{array}$ & 35.16 & 70.33 & 105.49 \\
\hline 10 & Moderate fall & 19.65 & 39.29 & 58.92 \\
\hline 11 & Light fall & 19.19 & 38.38 & 57.56 \\
\hline 12 & Heavy fall & 16.68 & 33.35 & 50.03 \\
\hline
\end{tabular}

those reported by other researchers (e.g., Cordingly and Kearl 1975; Stevens and Godfrey 1976; and Nielsen and Hinkely 1975), but they also indicate the pattern of utilization (season and intensity) can have a major impact on the returns obtained. The different utilization patterns that have been implicitly assumed (e.g., take half and leave half) by other researchers probably represent one of the major reasons why the returns reported have varied widely.

While the preceding analysis indicates that the Point Springs seedings yielded net returns that were greater' than the costs incurred, this analysis is not complete. The major reason why the returns reported above are not complete is the fact that these seedings are being used at the present time-i.e., benefits continued beyond 1970. A simulation model was therefore developed which estimated the effect of other patterns of utilization and ecological parameters on forage production. These simulated amounts of forage production were then used to evaluate what returns could have occurred under circumstances which were different from the actual gains which occurred at Point Springs.

\section{Simulated Returns}

A uniform set of data concerning forage production, utilization, precipitation, animal response, and other parameters was collected for each Point Springs pasture for the 1957 through 1970 grazing seasons. This data set $^{4}$ was used to estimate the following forage production equation:

$$
\begin{aligned}
& Y=-6489.3-5.62 X_{1}-5.1 X_{2}+221.1 X_{3}+95.54 X_{4}+48.3 X_{5} \\
& (5.05) \quad(4.76) \quad(1.17) \quad(4.92) \quad(1.58) \\
& +66.32 X_{6}+33.67 X_{7}-1.81 X_{\sharp} \text { where } \\
& (5.25) \quad(2.86) \quad(1.23)
\end{aligned}
$$

Sensitivity analysis was performed for cattle prices as low as $15 \%$ per pound and for various interest rates. Only in cases where the interest rate was greater than $9 \%$ and cattle prices were 158 did any (heavy fall) of the net returns become less than the initial costs.

Many statistical problems were encountered in estimating forage production and animal response functions from these data. This report contains the equations that were judged to be the most acceptable. Readers desiring additional detail regarding these estimations should see Godfrey and Sellasie (1978). I values for the regression coefficients are shown in parenthesis below the respective coefficient. 
$Y=$ total amount of forage produced per acre

$X_{1}=$ spring utilization in percent for the previous year

$X_{2}=$ fall utilization in percent for the previous year

$X_{: 3}=$ time $=$ year minus 1900

$X_{4}=$ inches of precipitation, November through March

$X_{5}=$ inches of precipitation in April

$X_{i j}=$ inches of precipitation in May and June

$X_{i}=$ inches of precipitation. July through October

$X_{\kappa}=X_{3}$ squared

Thus, for example, the predicted amount of forage produced in a pasture grazed at a $50 \%$ utilization rate in the spring and a $30 \%$ rate in the fall, with the average rainfall pattern for the Point Springs area in 1967, would be 515.98 pounds per acre-i.e., $1-6489.3-5.62(50)-5.1(30)+221.1(67)+$ $95.5+(3.44)+48.3(1.06)+66.32(3.86)+33.67(3.41)-$ $\left.1.81(67)^{2}\right]$.

Some of the regression coefficients above were not statistically significant at high levels of confidence. For example, variables $X_{3}(t=1.117)$ and $X_{8}(t=1.23)$ were not significantly different from zero at a probability level of less than $90 \%$. While there is no statistical reason why these time variables should be retained, they were needed to simulate production over time. Variables having high $t$ values were the variables which were expected to explain most of the variation. These were generally the same variables, primarily precipitation, that have shown high significance by other researchers (e.g., Currie and Peterson 1966; Sneva and Hyder 1962; and Sharp 1970). In the discussion that follows, precipitation during the periods indicated in the above forage production equation were assumed to be normal (mean values were used), utilization was allowed to vary, and the resultant forage production over time was estimated.

After the amount of forage that would be produced under the various simulated conditions was estimated, it was necessary to convert these amounts to animal production. This was accomplished by multiplying the applicable forage produced by the percent consumed. These forage consumption estimates were then multiplied by 7.5 if spring grazing occurred, and by 30 if fall grazing occurred." This yielded the expected amount of gain per acre that would be obtained. The 1.6 pounds of gain per acre that was assumed would occur without the project was then subtracted from this simulated gain. The resultant net gain was then multiplied by various beef prices to obtain net revenue. These amounts were then discounted for comparison with investment costs. These simulated net returns are shown in Table 2.

Several interesting inferences are shown by the data in Table 2. "First, whenever an area was grazed during the spring, the estimated net returns were greater than investment costs incurred. However, if crested wheatgrass is grazed only at low rates of utilization (e.g., $20 \%$ ) during the fall, the benefits in terms of animal gain may not be as great as the investment costs incurred. Second, heavy utilization, as was expected, resulted in the shortest project life (project life was determined when the simulated forage production yielded the "without" production

These coefficients represent the amount of forage consumed per pound of gain. The spring coefficient $(7.5)$ was assumed by Sharp. while the fall coefficient $(30)$ was the average amount of forage consumed per pound of gain on fall-grazed pastures. It should be noted that the average amount of forage consumed per pound of gain varied by year. season. and intensity of use. The coefficients indicated above were used because the animal gain equations that were estimated were rejected for various statistical reasons.

Readers should realize that these results could be modified if better estimates of forage production over time were available, and that the simulations involve extrapolations. These extrapolations would probably yield longer project lives if a better estimating equation was available. The project lives reported in Table 2, however, are nearly as long as most other researchers have reported.
Table 2. Estimated present value of increased net gains per acre under assumed management conditions, 1955 through end of project life.

\begin{tabular}{|c|c|c|c|c|c|}
\hline \multirow{2}{*}{$\begin{array}{l}\text { Percent } \\
\text { spring } \\
\text { utilization } \\
\quad\left(X_{1}\right)\end{array}$} & \multirow{2}{*}{$\begin{array}{l}\text { Percent } \\
\text { fall } \\
\text { utilization } \\
\quad\left(X_{2}\right)\end{array}$} & \multirow{2}{*}{$\begin{array}{l}\text { Project } \\
\text { life } \\
\text { (years)* }\end{array}$} & \multicolumn{3}{|c|}{ Price per pound ( $6 \%$ discount rate) } \\
\hline & & & $15 \notin$ & $30 \notin$ & $45 \phi$ \\
\hline 80 & 0 & 24 & 92.90 & 185.80 & 278.70 \\
\hline 60 & 0 & 26 & 86.15 & 172.30 & 258.45 \\
\hline 40 & 0 & 27 & 68.20 & 136.40 & 204.60 \\
\hline 60 & 20 & 24 & 76.60 & 153.20 & 229.80 \\
\hline 40 & 20 & 26 & 65.05 & 130.10 & 195.15 \\
\hline 40 & 40 & 24 & 59.55 & 119.10 & 178.60 \\
\hline 20 & 0 & 29 & 38.50 & 77.00 & 115.50 \\
\hline 20 & 20 & 27 & 42.10 & 84.20 & 126.30 \\
\hline 20 & 40 & 26 & 43.15 & 86.30 & 129.45 \\
\hline 20 & 60 & 24 & 41.70 & 83.40 & 125.10 \\
\hline 0 & 80 & 24 & 23.05 & 46.10 & 69.15 \\
\hline 0 & 60 & 26 & 20.40 & 40.80 & 61.20 \\
\hline 0 & 40 & 28 & 15.20 & 30.40 & 45.60 \\
\hline 0 & 20 & 29 & 7.30 & 14.60 & 21.90 \\
\hline
\end{tabular}

Project life plus $195+$ equals the year when the forage production is pedicted to equal the " w ithout " level of production. The length of life of these seedings is probably underestimated by the equation used.

of 1.6 pounds of gain per acre). Third, even though heavy utilization resulted in the shortest project life, the increased gain and resultant net returns more than offset the shorter project life. Thus, crested wheatgrass stands which are not subject to soil erosion could be used at relatively heavy rates of utilization. When productivity decreases, they could be reseeded or rested, and subsequently used at a heavy rate again. This would result in a utilization pattern similar to short rotation cycles in forest management-i.e., graze the area heavily for a relatively short period of time, reseed it, and start another cycle, versus a pattern of utilization involving a relatively low rate of utilization, which would extend the life of the project. Fourth, seeding an area to crested wheatgrass is a relatively beneficial expenditure of funds, from an animal production point of view, if these areas are grazed during the spring by yearling cattle, ${ }^{7}$ particularly if grazed at relatively high rates. Fifth, the manner in which a seeding is grazed has, perhaps, the largest impact on returns obtained.

\section{Conclusions}

Several major conclusions can be made from the above. These conclusions also agree, in general, with those recommended by Sharp (1970), but differ to some degree from the recommendations made by Currie (1970).

1. Investments made to establish the crested wheatgrass seedings at Point Springs were relatively beneficial from an animal production point of view.

2. Grazing crested wheatgrass during the spring is a necessary prerequisite to high net returns.

3. Heavy utilization resulted in the highest net returns. Thus, if an area can be grazed at a high rate without destroying the area's integrity (e.g., soil erosion), this will result in the greatest net returns.

4. Grazing at heavy rates during the spring was a somewhat superior utilization pattern to spring-fall utilization.

The high results obtained may not be indicative of other types of operations (e.g. $(c o w-c a l f)$. The high animal gains reported during the spring indicate that most livestock operators would find the types of seedings reported above to be profitable, nevertheless. 
5. Spring only or spring-fall use was clearly superior to a fall only utilization pattern.

6. Utilization of crested wheatgrass results in relatively low net returns in the form of domestic animal production, if grazing only occurs during the fall.

7. Variations due to differences in the pattern of utilization may be a major reason why diversified results have been reported by researchers which have evaluated the costs and returns of various range improvement practices.

Range managers must therefore carefully weigh the management practices they advocate if maximum gains are to be achieved. Grazing practices which emphasize plant production, with little consideration of the impact on animal response, may not result in highest animal gains. This may be particularly true in cases where light utilization, which favors a long project life, versus heavier utilization and a shorter period is advocated. In short, season of use, as well as intensity, makes a big difference in the returns that can be expected from range improvement investments.

\section{Bibliography}

Caton, D.D., and Christopher Beringer. 1960. Costs and benefits of reseeding rangelands in southeastern Idaho. Idaho Agr. Exp. Sta. Bull. 326. $31 \mathrm{p}$.

Currie, P.O., and B. Peterson. 1966. Using growing season precipitation to predict crested wheatgrass yields. J. Range Manage. 19:284-288.

Currie, Pat O. 1970. Influence of spring, fall and spring-fall grazing on crested wheatgrass. J. Range Manage. 23: 103-109
Godfrey, E. Bruce, and Ephraim Sellassie. 1978. The economic returns from seeding an area to crested wheatgrass: the Point Springs experiment. Idaho Agr. Exp. Sta. Bull. (in press).

Heady, Harold F. 1975. Rangeland Management. McGraw-Hill Book Co., New York. 460 p.

Kearl, W. Gordon, and Robert V. Cordingley. 1975. Costs and returns from reseeding plains ranges in Wyoming. J. Range Manage. 28: 437-442.

LeBaron, Allen. 1963. A discussion - the internal rate of return and decisions to improve range. In: Report No. 5 of the Committee on Economics of Range Use and Development, Western Agr. Econ. Res. Counc. Laramie. p. 117-127.

McKean, Roland. 1958. Efficiency in Government through Systems Analysis. Wiley. New York. 336 p.

Merewitz, L., and Stephen Sosnick. 1971. The Budget's New Clothes. Markham Publishing Co. St Paul. 660 p.

Neilsen, Darwin B., and Stan D. Hinckley. 1975. Economic and environmental impacts of sagebrush control in Utah's rangelands - a review and analysis. Utah Agr. Exp. Sta. Res. Rep. No. 25. 27 p.

Nielsen, Darwin B. 1977. Economics of range improvements: a rancher's handbook to economic decision-making. Utah Agr. Exp. Sta. Bull. 466. 52 $\mathrm{p}$

Prest, A.R., and Ralph Turvey. 1975. Benefit cost analysis: a survey. Econ. J. 75(300): 683-735.

Sharp, Lee A. 1970. Suggested management programs for grazing crested wheatgrass. Forest and Wildl. and Range Exp. Sta. Bull. No. 4, Univ. of Idaho, Moscow. $19 \mathrm{p}$

Sneva, F.A., and D.N. Hyder. 1962. Estimating herbage production on semiarid range in the intermountain region. J. Range Manage. 15: 88-93. Stevens, Joe B., and E. Bruce Godfrey. 1976. An economic analysis of public range investments on the Vale project, 1960-69. Oregon Agr. Exp. Sta. Circ. of Inform. 653. 19 p.

Stoddart, Lawrence A., Arthur D. Smith, and Thadis W. Box. 1975. Range Management. McGraw-Hill, New York. 532 p.

FOR INFORMATION

WRITE:

Dept. F.A.

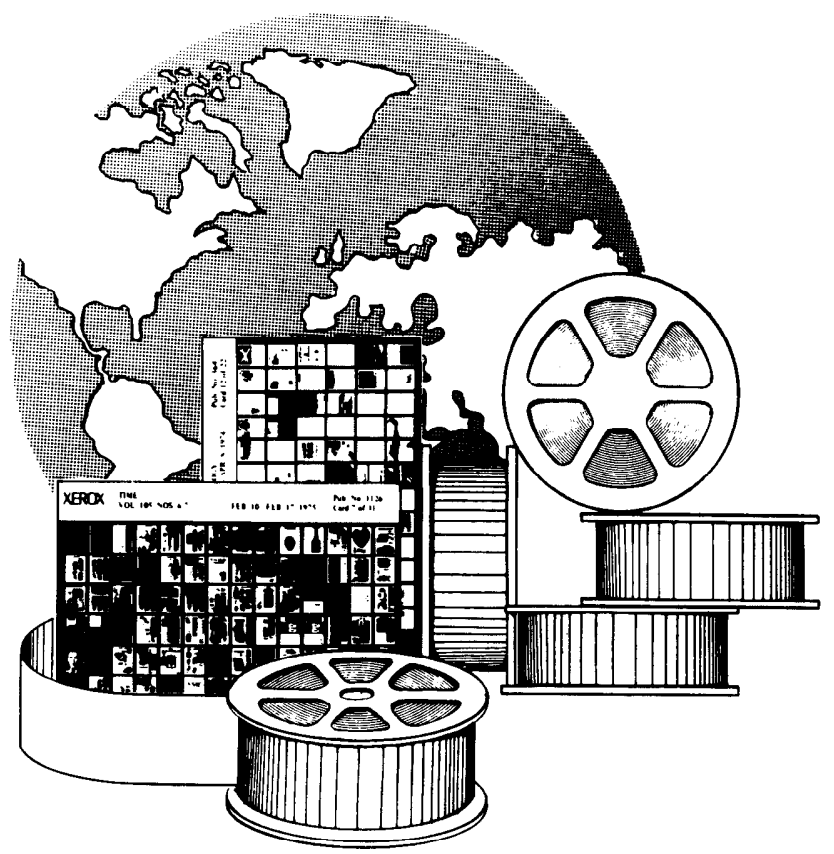

University Microfilms International

300 North ZeebRoad

Ann Arbor, Mich. 48106

U.S.A.
18 Bedford Row

London, WC1R 4EJ

England 